\title{
FRANŠIZA - MODEL ZA RAZVOJ PODUZETNIŠTVA
}

\author{
izv. prof. dr. sc. Aleksandar Erceg \\ Sveučilište Josipa Jurja Strossmayera u Osijeku, Ekonomski fakultet u Osijeku \\ Trg Ljudevita Gaja 7, Osijek, Hrvatska \\ e-mail: aleksandar.erceg@efos.hr \\ Ivana Orban, univ. spec. oec. \\ Požeško-slavonska županija, Hrvatska \\ e-mail: ivana.orban27@gmail.com
}

\section{SAŽETAK}

Prilikom pokretanja poslovnog pothvata potrebno je imati razrađenu strategiju poslovanja u kojoj se poduzetnici, između ostalog, bave i problemom nedovoljne popularnosti njihovih usluga. Jedan od načina pokretanja poduzetničkog pothvata je i kupovina franšize. Ulaskom u franšizni odnos poduzetnik na samom početku poslovanja može zaobići „početničke“ probleme i premostiti poslovne prepreke s obzirom na to da davatelj franšize nudi dokazanu strategiju i metodologiju poslovanja kao i potrebno znanje. Rad obrađuje pokretanje poduzetničkog pothvata kroz kupovinu franšize. Obrađuje se franšizni odnos te prednosti $i$ nedostatke ove vrste poduzetničke alternative za uključene strane te proces kupovine franšize s potrebnim koracima. Kupnja franšizne praonice rublja istražena je u kontekstu prednosti koju ovakva vrsta poslovanja ima u odnosu na samostalno pokretanje poslovnog pothvata nekoga tko nema predznanje u predmetnoj industriji. U radu su opisani koraci kupnje franšize na temelju prijedloga poslovne suradnje dobivenog od jednog svjetskog franšiznog brenda. $U$ cilju analize potencijalnih rizika pokretanja poslovanja napravljena je analize isplativosti, a oni se u najvećoj mjeri odnose na činjenicu da razvoj uslužnih franšiza, između ostalog, ovisi i o promjenama u društvenim navikama i stavovima. Rezultati provedenog istraživanja rada može biti korisno svim pojedincima koji razmišljaju o pokretanju poslovnog pothvata putem kupnje franšize.

Ključne riječi: poslovna prilika; poduzetnički pothvat; franšiza, primatelj franšize 


\section{UVOD}

Pokretanje poslovnog poduhvata povezano je s poduzetništvom koje je moguće definirati kao proces prepoznavanja prilike, prikupljanja sredstava za njenu realizaciju, stvaranja i raspodjele novostvorene vrijednosti. $U$ tom procesu, poduzetnik je osoba koja preuzima rizik u novcu, vremenu i ugledu (Brusić et al., 2009, 14). Stoga je potrebno prepoznati poslovnu priliku koja je proizvod interakcije između ideja, okolnosti u stvarnom svijetu i poduzetničke kreativnosti (Timmons, 1999, 81). Upravo je prilika glavni čimbenik Timmonsovog modela poduzetničkog procesa prema kojem proces započinje s prilikom koja je često veća od talenta i kapaciteta poduzetnika.

Nakon uočavanja poslovne prilike te kod donošenja odluke o pokretanju poslovnog poduhvata potencijalni poduzetnik ima nekoliko potencijalnih mogućnosti. One uključuju pokretanje vlastitog poduzeća (start-up), kupnja postojećeg poduzeća, nasljeđivanje poduzeća od člana obitelji te kupovina franšize. Dwivedy (2002) ističe kako franšizni poslovni model utječe na transfer tehnologije i poslovnih metoda te na povećanje ponude kvalitetnih proizvoda i usluga po kupcima prihvatljivim cijenama. Castrogiovanni i Justis (1998) navode kako je franšizni poslovni model jedan od najbrže rastućih oblika poslovanja u globalnoj ekonomiji. Samim time franšiza predstavlja privlačan način pokretanja poduzetničkog pothvata.

Franšiza prema Stanworthu $(1991,176)$ predstavlja ekonomsku kategoriju koja nudi povoljnu kombinaciju ekonomije obujma koju uživa davatelj franšize sa širokim mogućnostima koje posjeduje primatelj franšize u vezi s prilikama na lokalnom tržištu, a Boroian i Boroian $(1987,4)$ je definiraju kao odnos kada tvrtka (davatelj franšize) licencira svoje trgovačko ime (brend) i svoj način rada (sistem poslovanja) određenoj osobi ili grupi (primatelju franšize) koja se slaže da će poslovati u skladu s uvjetima ugovora (ugovor o franšizi). Drugi autori (Emmerson, 1990; Mlikotin-Tomić, 2000; Erceg, 2017) daju slične definicije franšize koristeći različita stajališta odnosno poglede iz raznih disciplina. Svaki franšizni sustav treba se temeljiti na četiri osnovne karakteristike: (i) vlasništvo nad brendom; (ii) licenca; (iii) struktura pristojbi i (iv) ugovor o franšizi (Weber, 2013). Franšizni poslovni model omogućuje davatelju franšize brži rast i širenje poslovanja što se smatra jednom od glavnih prednosti ovog poslovnog modela (Murray, 2003; Hisrich et al., 2011). S druge strane, Spasić (1996) navodi kako su najznačajnije prednosti za primatelja korištenje uspješnim i poznatim imenom i reputacijom te kako se nedostatak znanja i iskustva može nadoknaditi obukom. Ulazak u franšizno poslovanje moguće je na dva načina: kupovinom franšize te projektiranjem i pokretanjem franšizne mreže.

U ovom radu bavit ćemo se kupovinom franšize kao načinom pokretanja poduzetničkog pothvata. U drugom poglavlju dane su teorijske postavke kupovine franšize. U trećem je prikazan proces kupovine franšize na primjer pokretanja uslužne praonice rublja. U četvrtom, završnom dijelu prezentiran je zaključak istraživanja te su dani prijedlozi za daljnja istraživanja. 


\section{PROCES KUPOVINE FRANŠIZE}

S obzirom da ulazak u franšizni način poslovanja zahtijeva puno vremena kako bi se sve istražilo i preispitalo, a potom i puno financijskih sredstava, prvo pitanje koje si svatko, tko razmišlja o kupnji franšize, treba postaviti je: Jesam li kvalificiran da postanem primatelj franšize, imam li sve osobine koje odlikuju primatelja? Prema Boroianu i Mancusu (1993, 32) primatelj franšize hibridni je oblik šefa i zaposlenika - primatelj je vlasnik svog poduzeća i vodi svoju franšiznu lokaciju, ali mora slijediti sustav i pravila davatelja franšize koji je usavršio svoje poslovanje. U zamjenu za stručnu pomoć i utemeljenu reputaciju koju prima od davatelja, primatelj franšize plaća postotak od prodaje. Da bi postao primatelj franšize, potrebno je imati određenu vrstu osobnosti sa specifičnim osobinama i temperamentom. Prije svega, potrebno je provjeriti raspolaže li potencijalni primatelj franšize tim osobinama, odnosno provjeriti sklonost primatelja franšizi. Najvažnije osobine koje se smatraju poželjnima za primatelja franšize, prema odgovorima ispitanika koji su sudjelovali u istraživanju davatelja franšiza Francorp/DePaul (Boroian i Mancuso, 1993) snažna su želja za učenjem i sposobnost primanja i slijeđenja uputa, spremnost na prekovremeni rad, visoko razvijene socijalne vještine kao i određena razina prodajnih vještina te sposobnost nošenja sa stresom. Ujedno, ukoliko potencijalni primatelj raspolaže i financijskim sredstvima, smatra se idealnim kandidatom. S druge strane, osobine poput prethodnog radnog iskustva u velikim poduzećima, prethodnog franšiznog iskustva ili prethodnog poduzetničkog iskustva odnosno nedostatku istog ne smatraju se ključnim osobinama koje potencijalni primatelj franšize mora imati. Nakon što potencijalni primatelj izvrši samoprocjenu svojih osobnih i profesionalnih vještina, sljedeći korak je istraživanje dostupnih franšiza prije donošenja konačne odluke o odabiru franšizne organizacije s kojom želi poslovati (Dugan, 1998). U ovom koraku potrebno je suziti izbor potencijalnih franšiza kako bi se pronašla ona savršena. Zatim je za određenu franšizu potrebno posjetiti sjedište davatelja franšize, pribaviti i analizirati svu potrebnu dokumentaciju konzultirajući se s pravnim i financijskim stručnjacima, pronaći i razgovarati sa sadašnjim primateljima franšize kao i onima koji su izašli iz franšiznog odnosa. Zatim je potrebno provjeriti potencijalne izvore financiranja te sagledati franšizu kao investiciju i provjeriti njenu isplativost. Prije nego se potencijalni primatelj obveže na kupnju određene franšize, potrebno je ispitati tu „transakciju“ u smislu njenog učinka kao investicije. Kupnja franšize investicija je u koju se ulažu vrijeme i novac zbog čega ju, kao i druge investicije, treba vrednovati temeljem procijenjenog povrata na investiciju. Prilikom analiziranja financijske isplativosti kupnje franšize, potrebno je razumjeti dva iznosa: visinu početne pristojbe i postotak tekućih tantijema koji se isplaćuju davatelju franšize. Važno je ne podcijeniti iznos financijskih sredstava koja su potrebna za kupovinu franšize.

Na sljedećih sedam mjesta treba tražiti izvore financiranja za kupovinu franšize (Boroian i Mancuso, 1993, 77):

- osobno bogatstvo (nekretnine, pokretnine, ušteđevina, umjetnine, nakit i druge vrijednosne stvari),

- obitelj i prijatelji,

- davatelj franšize,

- banke,
- leasing za kupnju opreme, namještaja i poslovnog prostora,

- javni izvori i

- fondovi rizičnog kapitala i/ili komanditno društvo. 
Nakon što su osigurana sredstva za financiranje, zadnji korak pravnog stručnjaka i financijskog savjetnika prije zaključenja kupovine pregledavanje je ugovora i financijskih pokazatelja. Nakon toga se postaje primateljem franšize. S obzirom na prethodno navedeno, u nastavku je prikazan sažetak svih koraka koje treba i koje ne treba napraviti prilikom kupovine franšize. (Tablica 1)

\section{Tablica 1. Aktivnosti koje treba i ne treba napraviti}

\begin{tabular}{|c|c|}
\hline Aktivnosti koje treba napraviti & Aktivnosti koje ne bi trebali napraviti \\
\hline $\begin{array}{l}\text { angažirati odvjetnika s iskustvom iz područja } \\
\text { franšize }\end{array}$ & $\begin{array}{l}\text { kupiti franšizu bez prethodnog istraživanja } \\
\text { povijesti poduzeća davatelja franšize i detaljnog } \\
\text { pregleda komercijalnog dosjea }\end{array}$ \\
\hline $\begin{array}{l}\text { izraditi poslovni plan koji uključuje osobne ciljeve, } \\
\text { snage i slabosti }\end{array}$ & $\begin{array}{l}\text { podcijeniti razdoblje prije nego se dosegne točka } \\
\text { pokrića }\end{array}$ \\
\hline $\begin{array}{l}\text { kontaktirati međunarodna ili nacionalna franšizna } \\
\text { udruženje kako bi se informirali o franšiznoj } \\
\text { industriji }\end{array}$ & $\begin{array}{l}\text { započeti poslovni odnos s davateljem franšize koji } \\
\text { nema potrebu istražiti pozadinu potencijalnog } \\
\text { primatelja franšize }\end{array}$ \\
\hline $\begin{array}{l}\text { pregledati sporazum o poslovnoj suradnji te } \\
\text { utvrditi koje geografsko područje on pokriva te } \\
\text { postoji li kakva zaštita u slučaju budućeg nastupa i } \\
\text { širenja konkurencije }\end{array}$ & $\begin{array}{l}\text { kupiti franšizu bez jasne slike o pristojbama koje } \\
\text { su uključene u franšizno poslovanje te saznanja o } \\
\text { proizvodima i uslugama za koje se očekuje da se } \\
\text { kupuju od davatelja franšize }\end{array}$ \\
\hline $\begin{array}{l}\text { provjeriti osiguravaju li se odgovarajuće edukacije } \\
\text { na početku i tijekom poslovanja }\end{array}$ & $\begin{array}{l}\text { kupiti franšizu bez saznanja o izdašnosti tehničke } \\
\text { pomoći, odnosno do koje mjere je ona dostupna } \\
\text { od strane davatelja franšize }\end{array}$ \\
\hline $\begin{array}{l}\text { upoznati vlasnika poduzeća davatelja franšize prije } \\
\text { kupovine franšize }\end{array}$ & ograničiti se na određenu vrstu proizvoda i usluge \\
\hline $\begin{array}{l}\text { pobrinuti se za raspolaganje zadovoljavajućom } \\
\text { razinom financijskih sredstva prije kretanja u } \\
\text { posao koji je izvan vlastitih financijskih mogućnosti }\end{array}$ & $\begin{array}{l}\text { konačno se opredijeliti se za određenu franšizu } \\
\text { bez razgovora s nekoliko primatelja te franšize, po } \\
\text { mogućnosti na njihovim lokacijama }\end{array}$ \\
\hline posjetiti sajmove franšiz & \\
\hline
\end{tabular}

Izvor: prilagođeno prema Borian i Mancuso, 1993.

Nakon što su pobrojane sve potrebne aktivnosti i odluke koje potencijalni primatelj franšize treba napraviti prije nego odluči kupiti franšizu, nameće se zaključak kako franšizno poslovanje može biti uspješna poduzetnička alternativa za „pravu“ vrstu ljudi. Važno je da potencijalni primatelj prije same kupnje bude svjestan što ga očekuje u franšiznom poslovanju, a pažljivo praćenje koraka za pokretanje franšize može se isplatiti u razdoblju koje će uslijediti nakon potpisa franšiznog ugovora.

Prema Ercegu $(2017,168)$ istraživanje i proučavanje franšizne ponude uključuje sastanak s davateljem franšize, pažljivo proučavanje franšizne ponude, traženje pravnih savjeta od odvjetnika koji se bavi franšiznim poslovanjem, traženje savjeta od financijskih savjetnika te sastanke sa sadašnjim primateljima franšize i s primateljima franšize koji su izašli iz sustava. Barringer i Ireland (2016) su proces kupovine prikazali kroz sedam koraka. (Slika 1) 


\section{Slika 1. Proces kupovine franšize}

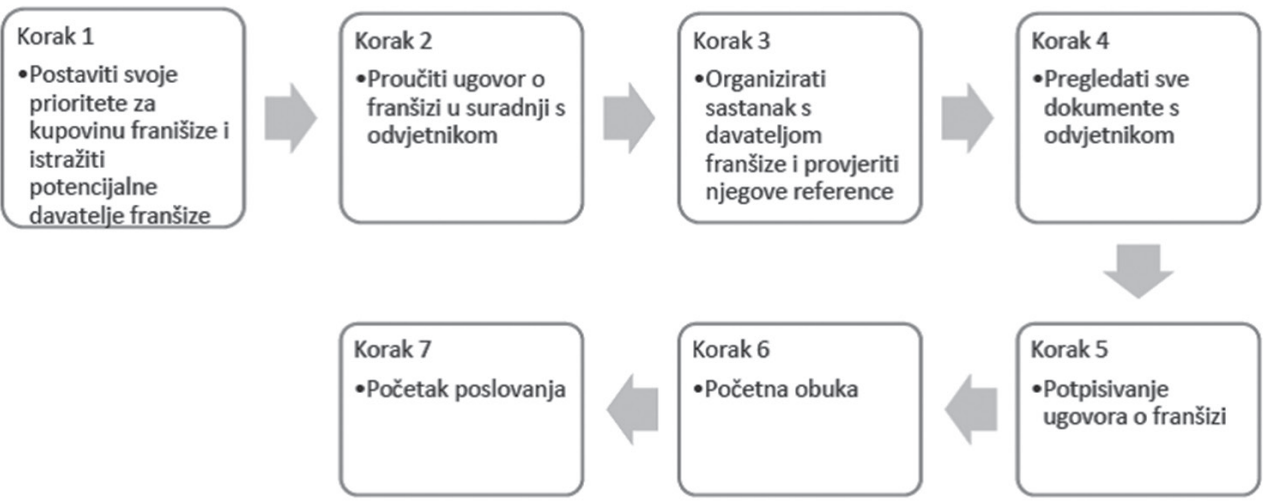

Izvor: prilagođeno prema Barringer i Ireland, 2016, 539

Prvi korak procesa odnosi se na slaganje liste prioriteta kako bi potencijalni primatelj franšize došao do određene „liste“ franšiznih prilika proizašle filtriranjem pomoću dostupnih online alata kao što su Franchise Selector Tool ili FranchiseHelp.com temeljem određenih kriterija kao što su primjerice industrija, lokacija, visina investicije i slično. Dobiveni rezultati se tada detaljnije istražuju ili se posjećuju sajmovi franšiza na kojima se prezentiraju identificirane franšizne prilike (Keup, 2000). Drugi korak u procesu kupovine franšize sastanak je s odvjetnikom koji se bavi franšiznim poslovanjem čija će zadaća biti zastupanje interesa primatelja. Odvjetnik će proučiti dokumentaciju, posebice franšizni ugovor te pripremiti primatelja franšize za sastanak s davateljem. S davateljem je ponekad moguće i pregovarati oko određenih stavki ugovora za što je potrebno pripremiti se (Murray, 2003). Treći korak procesa uključuje sastanak s davateljem franšize, preferabilno u sjedištu tvrtke. Tijekom sastanka potencijalni primatelj će uspoređivati informacije koje kroz razgovor dobije od davatelja s informacijama koje je prethodno prikupio od drugih trenutnih, ali i bivših primatelja franšize (Tomzack, 2002). Na sastanku potencijalni primatelj treba postaviti pitanja vezana uz povijest tvrtke (financijsko stanje i rezultati poslovanja), način obuke primatelja, pružanje potpore prilikom pokretanja i tijekom poslovanja, mogućnost rasta poslovanja primatelja, proces izlaska iz franšize, očekivani prihod i prodaja, prisutnost konkurencije i način nošenja davatelja s rizicima i prijetnjama iz okoline (Seid i Thomas, 2006). Sve informacije koje tijekom sastanka i naknadno primatelj dobije od davatelja franšize treba opetovano provjeriti. Sljedeći, četvrti korak je pregled sve primljene dokumentacije, uključujući franšizni ugovor, s odvjetnikom. Teoretski postoji mogućnost pregovaranja o uvjetima ugovora o franšizi, međutim davatelji u većini slučajeva neće biti spremni na kompromise. Štoviše, ako je davatelj spreman pregovarati o načinu ponude proizvoda ili usluga javnosti ili o visini pristojbi, primatelj si treba postaviti pitanje što je dogovarano s ostalim primateljima franšize jer se potencijalni primatelj, između ostalog oslanja na konzistentnost i postojanost postojećeg sustava franšize. Nakon pregleda dokumenata i eventualnih pregovora, slijedi peti korak - potpis ugovora o franšizi koji čini temelj odnosa između primatelja i davatelja franšize. Potpisom ugovora potencijalni investitor postaje primatelj franšize koji se obvezuje prihvatiti i pridržavati svih pravila koji vrijede za franšizni sustav koji je predmet ugovora. Posljednjem, sedmom, koraku procesa 
koji se odnosi na početak poslovanja, prethodi edukacija primatelja franšize i upoznavanje s procedurama i pravilima u provedbi svakodnevnih poslovnih aktivnosti. Veliki davatelji franšize imaju svoje posebno oformljene edukacijske centre u svojim glavnim uredima, ali edukacija se može provoditi i na lokaciji koju će voditi primatelj franšize (Tomzack, 2002; Seid i Thomas, 2006). Primatelj franšize tijekom obuke treba usvojiti proizvodnju i isporuku proizvoda ili usluga davatelja franšize tako da to bude svaki put na isti način (Dugan, 1998). Po završetku edukacije, primatelj franšize može otvoriti svoju lokaciju i započeti s poslovanjem. Proces kupovine franšize, predstavljen kroz prethodno navedenih sedam koraka dugotrajan je proces koji zahtijeva mjesece istraživanja putem interneta, posjeta sajmovima, razgovora s trenutnim i bivšim primateljima. Tek po završetku istraživanja kad primatelj sazna gotovo sve o davatelju franšize, može i treba donijeti odluku o njenoj kupnji (Barringer i Ireland, 2016).

\section{METODOLOGIJA ISTRAŽIVANJA}

Prilikom pisanja ovog rada koristili smo se metodom studije slučaja. Metodom studije slučaja dubinski se analizira neka pojava, proces, institucija, osoba, grupa ili događaj (Tkalec Verčić, et al., 2010, 102). Prilikom korištenja studije slučaja, uzorak je namjerno odabran na način da istraživač sam odabire „slučaj“ koji odgovara njegovom fokusu. Osnova ove metode kao vrste istraživanja je u proučavanju malog broja slučajeva ili čak samo jednog koji će se istražiti do detalja i u realnom kontekstu. Pitanja koja se postavljaju tijekom studije slučaja su zašto i kako.

Istraživanje provedeno u ovom radu bazira na slučaju pokretanja poduzetničkog pothvata kupovinom franšize. Korištenjem navedene metode istražen je razvoj i poslovni prijedlog kupovine franšize svjetskog brenda uslužnih praonica rublja koristeći se procesom sedam koraka kupovine franšize kojeg su predložili Barringer i Ireland (2016).

\section{KUPOVINA FRANŠIZE USLUŽNE PRAONICE RUBLJA}

U nastavku rada prikazan je proces kupovine franšize uslužne praonice rublja kao i sva potrebna istraživanja koja jedan potencijalni primatelj franšize treba provesti.

Industrija obrade rublja trenutno je jedna od najbrže rastućih industrija s obzirom da je zadnjih nekoliko godina zabilježen veliki porast u potražnji zbog čega su franšizne praonice rublja postale jedne od najprofitabilnijih poslovnih prilika. $U$ današnje je vrijeme sve kaotično, stres je sveprisutan i ljudi imaju sve manje i manje vremena za aktivnosti u kojima uživaju. Prema provedenim istraživanjima (MrJeff, 2020), pranje rublja zadatak je na koji može otići i do 500 sati godišnje što je ekvivalent prosječnom godišnjem odmoru. Zaključno, odluka o traženje franšize uslužne praonice rublja donesena je temeljem sljedećih činjenica: povećana potražnja za uslugom, velika većina ljudi smatra kako je pranje i peglanje rublja zamorna aktivnosti za koju bi bolje platili i tako si oslobodili vrijeme za posvetiti se aktivnosti koje žele, ljudi imaju sve manje slobodnog vremena zbog čega se povećava potražnja za ovakvom uslugom, korištenje usluge pranje i peglanja rublja na mjesečnoj razini isplativije je nego pranje i peglanje kod kuće jer se štedi na vodi, struji i sredstvima za pranje, vrsta usluge za kojom će uvijek postojati potražnja jer svatko treba prati svoje rublje, to je osnovna higijenska potreba. 


\subsection{Odabir franšize}

Na tržištu postoji puno franšiza samouslužnih praonica, u Hrvatskoj je najpoznatija LG Loundry Lounge (Bijeli svijet, 2017). Međutim, prilikom istraživanja tržišta fokus je zadržan na franšizama uslužnih praonica rublja, a ne samouslužnih iz razloga što samouslužne praonice podrazumijevaju više od 3 koraka: staviti rublje u vrećicu i otići do najbliže praonice rublja (u vrijeme kad je otvorena), pokrenuti proces pranja, čekati u praonici dok pranje ne bude gotovo te na koncu odnijeti oprano rublje kući što opet predstavlja gubitak vremena. Tijekom istraživanja franšiza uslužnih praonica rublja, dvije su se franšize istaknule svojim poslovnim putem i načinom poslovanja. To su franšize Pressto i (Mr) Jeff. Zajedničko im je da su obje pokrenute u Španjolskoj, a širenje svog poslovanja započele su u Latinskoj Americi. Pressto je franšizni brend uslužne praonice rublja iz Španjolske koji ima 400 lokacija smještenih u 25 zemalja diljem 5 kontinenata. Osnovan je 1994. godine u Madridu, a prva međunarodna franšiza je otvorena 1997. godine u Meksiku. Pressto je 2017. godine, drugu godinu za redom, uvršten na ljestvicu top 100 najboljih svjetskih franšiza i to kao jedan od ukupno 4 španjolska brenda na ljestvici. Jeff franšiza rublja brand je prisutan u 40 zemalja. Osnovan je 2015. godine u Valenciji, a prva franšizna lokacija je otvorena u prosincu 2017. godine u Latinskoj Americi. S obzirom na prethodno opisane korake u procesu kupnje franšize, a temeljem istraživanja provedenog u prvom koraku te početne ideje o otvaranju uslužne praonice rublja, daljnji koraci u procesu kupovine franšize bit će rađeni za Pressto franšizu praonice rublja.

\subsection{Proces odlučivanja}

Prema prijedlogu poslovne suradnje, cjelokupna investicija za pokretanje Pressto franšize podijeljena je na troškove prve pilot jedinice, standardnih jedinica i prikupnog mjesta kao što je prikazano u Tablici 2. Troškovi uključuju početnu pristojbu, radne strojeve, uređenje prostora i prvu zalihu potrepština, dok troškovi građevinskih radova nisu uključeni.

Tablica 2. Prosječna visina investicije za pojedina Pressto prodajna mjesta

\begin{tabular}{|l|c|}
\hline Pressto lokacije & Iznos* \\
\hline Prva pilot jedinica s kompletnom opremom, $150 \mathrm{~m}^{2}$ & $127.730 €$ \\
\hline Standardne prodajne jedinice, $70-100 \mathrm{~m}^{2}$ & $95.700 €$ \\
\hline Prikupno mjesto, $30-60 \mathrm{~m}^{2}$ & $34.404 €$ \\
\hline
\end{tabular}

*Podaci prikazani u tablici predstavljaju sažetak analitičkog istraživanja tržišta koje je poduzeće Pressto (2020) izradilo za Hrvatsku. Detaljno raščlanjivanje troškova se provodi kasnije sa zainteresiranim stranama. Izvor: prilagođeno prema prijedlogu poslovne suradnje Pressto

U nastavku su prikazane tablice (3. i 4.) s razradom troškova prve godine poslovanja za jednu pilot jedinicu i jedno prikupno mjesto. lako prikupno mjesto nije uvjetovano, Presstova preporuka je imati ga kako bi svojom uslugom pokrili veći određene geografske lokacije. 
Tablica 3. Visina investicije za prvu godinu poslovanja

\begin{tabular}{|l|c|c|}
\hline Ukupna investicija za prvu godinu & Potrebno & Preporučeno \\
\hline Pristojba za master franšizu & $85.000 €$ & $85.000 €$ \\
\hline 1 Pilot jedinica & $171.930 €$ & $171.930 €$ \\
\hline 1 prikupno mjesto & & $44.604 €$ \\
\hline UKUPNO & $256.930 €$ & $301.533 €$ \\
\hline
\end{tabular}

Izvor: prilagođeno prema prijedlogu poslovne suradnje Pressto

Tablica 4. Ukupan iznos koji primatelj franšize mora platiti poduzeću Pressto prve godine

\begin{tabular}{|l|c|}
\hline \multicolumn{2}{|c|}{ Ukupan iznos koji se plaća davatelju franšize prve godine } \\
\hline Pristojba za master franšizu & $85.000 €$ \\
\hline 1 kompletno opremljena (strojevi, uređenje prostora, prva zaliha potrepština) pilot jedinica & $109.109 €$ \\
\hline 1 prikupno mjesto & $20.315 €$ \\
\hline UKUPNO & $\mathbf{2 1 4 . 4 2 3}$ \\
\hline
\end{tabular}

Izvor: prilagođeno prema prijedlogu poslovne suradnje Pressto

Pressto svoje međunarodno širenje prakticira kroz master franšize gdje primatelj franšize može otvarati vlastite lokacije te se širiti kroz podfranšize. Financijske projekcije izrađene u poslanom prijedlogu poslovne suradnje odnose se na prihode ostvarene od vlastitih lokacija primatelja master franšize, a ne prihoda od podfranšiza. Operativni rezultati poslovanja primatelja master franšize rađeni su na pretpostavci posjedovanja 10 vlastitih lokacija čiji ukupni rezultati poslovanja za petogodišnje razdoblje iznose 7.371.071 €. Povrat ulaganja kao pokazatelj rentabilnosti i profitabilnosti investicije za Pressto primatelja franšize iznosi 6,02. Visok povrat uloženih sredstava podrazumijeva povoljno ulaganje (Tablica 5).

\section{Tablica 5. Povrat ulaganja investicije}

\begin{tabular}{|c|c|c|c|c|c|}
\hline \multicolumn{4}{|c|}{ Ukupni rezultati poslovanja vlastitih lokacija } & \multicolumn{2}{|c|}{$7.371 .071 €$} \\
\hline \multicolumn{3}{|c|}{ Visina investicije } & & \multicolumn{2}{|c|}{$1.050 .683 €$} \\
\hline \multirow{2}{*}{$\mathrm{ROI}=$} & Prihod investicije - Trošak investicije & \multirow{2}{*}{$=$} & 7.371.071- 1.050 .683 & \multirow{2}{*}{$=$} & \multirow{2}{*}{6,02} \\
\hline & Trošak investicije & & 1.050 .683 & & \\
\hline
\end{tabular}

Izvor: izračun autora

Pristojba za master franšizu početna je pristojba koja primatelju master franšize daje ekskluzivno pravo da razvija određeni brend na nekom području. Pristojba za Pressto master franšizu iznosi $85.000 €$. Pristojba za vlastitu lokaciju bilo kog formata iznosi 3.000 
$€$, a ukoliko primatelj master franšize daje i podfranšize, pristojba koju plaća davatelju iznosi 30\% franšizne pristojbe koju njemu plaća primatelj podfranšize.

Tantijemi koje primatelj master franšize plaća davatelju za korištenje brenda i koncepta poslovanja iznose 3\% ostvarenog prometa na mjesečnoj bazi za vlastite lokacije, dok za podfranšize iznose $1,5 \%$. Tantijemi su iznos koji primatelj franšize plaća davatelju za korištenje franšiznog brenda i sistema poslovanja.

Marketinška pristojba za Pressto franšizu je predložena u iznosu od 2\% ukupnih prihoda te će njome upravljati primatelj master franšize. Marketinška pristojba je doprinos za promociju koji primatelj franšize u obliku postotka od ostvarenih prihoda uplaćuje u zajedničku blagajnu davatelja s ciljem promoviranja cijele franšizne mreže na određenoj razini (regionalno ili nacionalno).

\subsection{Tržišna opravdanost}

Prema istraživanju Dry-Cleaning And Laundry Services Global Market Opportunities And Strategies To 2022 (Businesswire, 2019) globalno tržište kemijskih čistionica i praonica rublja doseglo je vrijednost od gotovo 118,9 milijardi dolara 2018. godine pri čemu je od 2014. godine raslo po stopi od $8,7 \%$ te se očekuje da će i dalje rasti po stopi od $10,9 \%$ do vrijednosti od gotovo 180 milijardi dolara 2022. godine. Od 2014. do 2018. godine rast je proizlazio iz snažnog ekonomskog rasta na tržištima u nastajanju, brze urbanizacije, porasta broja samačkih domaćinstava kao i rasta u uslužnom zdravstvenom sektoru. Čimbenici koji su negativno utjecali na rast u navedenom periodu bili su porast osobnih preferencija za pranjem kod kuće, pojava multifunkcionalnih kućanskih aparata, porast cijena zakupa poslovnih prostora kao i niske profitne marže. Predviđanja za budućnost govore kako će daljnji rast poticati rast u ugostiteljskom sektoru, povećane prilike za franšizama, ekonomski rast, ubrzani životni tempo te tehnološka unaprjeđenja u industriji obrade rublja. S druge strane, čimbenici koji bi mogli kočiti rast tržišta kemijskih čistionica i praonica rublja su porast minimalnih plaća, nedostatak kvalificirane radne snage, niska penetracija servisne obrade rublja u zemljama u razvoju kao i promjenjiva zakonska regulativa.

Današnji životni tempo je ubrzan i prepun obveza uslijed čega pojedinac (većinom žene) i ono malo slobodnog vremena što im preostane (vikendom) troše na rublje (pranje i glačane) umjesto da ga provedu na način koji će ih relaksirati i usrećiti. Dakle, ciljna skupina su zaposlene žene koje, uz poslovne i druge obiteljske obveze, dobivaju mogućnost izbora: osigurati si slobodno vrijeme za bavljenje onim što vole ili ga trošiti na rublje. Dio ciljnog tržišta su i zaposlene muške osobe (samci) koji također svoje slobodno vrijeme žele trošiti na nešto što ih ispunjava umjesto na aktivnost koja im sama po sebi „nije prirođena“. Dodatno, svjedoci smo starenja ukupnog stanovništva. Puno je osoba starije životne dobi koji žive sami i kojima je potrebna pomoć. Oni također čine ciljnu skupinu. Osim privatnog sektora koji čini većinu, Pressto uslužna praonica orijentirana je i na poslovni sektor, međutim ne na industrijsku obradu rublja s obzirom da ista zahtijeva potpuno drugačije radne strojeve i postupke obrade, već na obradu radne odjeće i uniformi. Način povezivanja s ciljnim tržištem definira se marketinškom strategijom koja će biti detaljno razrađena u suradnji s davateljem franšize. 


\subsection{Isplativost kupovine franšize}

Nakon identifikacije ciljnog tržišta i razumijevanja poslovnog koncepta, za donošenje odluke o kupnji franšize, potrebno je proučiti i financijski dio koji se odnosi na procjenu prihoda, troškova i očekivanu dobit. Financijske su projekcije rađene na temelju sljedećih pretpostavki:

- Primatelj će kroz 5 godina otvoriti 10 vlastitih lokacija Pressto brenda (1 pilot jedinica, 1 standardna jedinica i 8 prikupnih mjesta)

- Visina mater franšizne pristojbe iznosi $85.000 €$

- Godišnja pristojba za održavanje i tehničku pomoć iznosi $4.000 €$

- Tantijemi za vlastite lokacije iznose 3\% ostvarenog prihoda

- Početna pristojba za vlastite lokacije iznosi $3.000 €$

- Vrijeme trajanja master ugovora o franšizi je 10 godina uz mogućnost produženja na dodatni period od 10 godina

- Tantijemi od podfranšiza iznose 5\% ostvarenih prihoda od čega 3,5\% ide davatelju franšize, a 1,5\% primatelju master franšize.

Poslovni plan pokriva srednjoročni petogodišnji period tijekom kojeg je planirano otvoriti ukupno deset vlastitih lokacija (jedna pilot jedinica, jedna standardna jedinica i osam prikupnih mjesta). U prvoj godini poslovanja, izlazak na hrvatsko tržište ostvarit će se putem jedne pilot jedinice popraćene jednim prikupnim mjestom. Procijenjena je investicija najviša u prvoj godini pri otvaranju poslovne jedinice i iznosi 217 tisuća eura, a u preostalom periodu se očekuje konstantno ulaganje u investicije. Iznimka je jedino u trećoj godini poslovanja kad se planira pokretanje dodatne standardne jedinice. Kada se gledaju operativni troškovi razvoja (naknade, tantijemi, osiguranja), vidljivo je kako je u troškovnu bazu uključena inflacija od 3\%. Za svaku pojedinu vrstu lokacija se točka pokrića postiže već u prvoj godini poslovanja ako uzmemo u obzir 288 radnih dana. Početna investicija u prvoj godini iznosi 302 tisuće eura s uključenom master franšizom. Prema poslovnom planu, svaka poslovna lokacija pokazuje visoku bruto (+90\%) i operativnu maržu (+60\%) što rezultira visokom stopom povrata na investiciju od 6,02 za ukupnu investiciju od 1 milijun eura i 7 milijuna eura operativnog profita (prije kamata i poreza). Prikazane projekcije ukazuju na isplativost pokretanja poduzetničkog pothvata kupovinom franšize uslužne praonice rublja Pressto.

Ono što je potrebno napomenuti kako su dane sve financijske projekcije rađene uz ogradu davatelja franšize koji ne jamči predviđene rezultate i uspjeh franšize na ugovorenom području. Ovo će ovisiti o postavljenim ciljevima koji moraju odgovarati realnosti sektora u datom području te poslovanju primatelja franšize u skladu s obrascima poslovanja davatelja kao i o situaciji na tržištu na kojem se želi pokrenuti poduzetnički pothvat kupovinom spomenute franšize. 


\section{ZAKLJUČAK}

Kod odluke o pokretanju poduzetničkog pothvata, potencijalni poduzetnik ima nekoliko mogućnosti. Jedna od njih je pokretanje poduzetničkog pothvata kupovinom franšize. Franšiza omogućava potencijalnom poduzetniku pokretanja pothvata uz manji rizik jer kupovinom franšize dobiva i potporu davatelja franšize koji mu pomaže svojim savjetima i prenosi znanje o poslovanju. Kupovina franšize i ulazak u franšizni poslovni odnos izrazito je kompleksan proces kojem s najvećom pažnjom treba pristupiti upravo na početku tog procesa kad se odlučuje za određenu franšizu. Primjenjujući istražene korake za kupovinu franšize, pojedinac može realizirati svoju poslovnu ideju uz pomoć iskusnog i stabilnog "mentora" - davatelja franšize te na njoj zaraditi.

Promatrani slučaj kupovine franšize uslužne praonice rublja radi pokretanja poduzetničkog pothvata pokazuje iznimnu važnost praćenja procesa kupovine franšizne lokacije tijekom svih njegovih faza. Promatranje troškova kao i potencijalne zarade ukazuju na isplativost u ovom slučaju, no uz napomenu kako svako tržište ima svoje posebnosti koje davatelj franšize ne uključuje u svoje financijske prognoze. Upravo ta posebnost tržišta na kojem potencijalni primatelj franšize pokreće svoj poduzetnički pothvat kao i njegovo znanje o tržištu ,jezičac“ je na vagi koji dijeli uspjeh od neuspjeha u poslovanju.

Na osnovi provedenog istraživanja slučaja kupovine franšize za pokretanje poduzetničkog pothvata predlažemo daljnja istraživanja vezana za uspjeh u franšiznom poslovanju u različitim industrijskim sektorima kako u Republici Hrvatskoj tako i u zemljama u okruženju. 


\title{
FRANCHISING - A MODEL FOR ENTREPRENEURSHIP DEVELOPMENT
}

\author{
Aleksandar Erceg, Ph.D., Associate professor \\ Josip Juraj Strossmayer University of Osijek, Faculty of Economics in Osijek \\ Trg Ljudevita Gaja 7, Osijek, Croatia \\ e-mail: aleksandar.erceg@efos.hr \\ Ivana Orban, univ. spec. oec. \\ Požega-Slavonia County, Croatia \\ e-mail: ivana.orban27@gmail.com
}

\begin{abstract}
When starting a business venture, it is necessary to have an elaborate business strategy in which entrepreneurs, among other things, deal with the problem of scarce popularity of their services. One way to start an entrepreneurial venture is to buy a franchise. By entering a franchise relationship, at the very beginning of the business, the entrepreneur can avoid "beginner" problems and overcome business obstacles, given that the franchisor offers a proven business strategy and methodology as well as the necessary knowledge. The paper deals with starting an entrepreneurial venture through the purchase of a franchise. The paper discusses a franchise relationship and the advantages and disadvantages of this type of entrepreneurial alternative for the parties involved. It also observes the process of buying a franchise together with the necessary steps. The purchase of a laundry franchise has been explored in the context of the advantage that this type of business has over starting a business venture by someone who has no prior knowledge in this particular industry. The paper describes the steps of buying a franchise based on a business cooperation proposal received from a global franchise brand. In order to analyze the potential risks of starting a business, cost-effectiveness analyses were made, and they are mostly related to the fact that the development of service franchises, among other things, depends on changes in social habits and attitudes. The results of the conducted research work can be useful to all individuals who are considering starting a business venture through the purchase of a franchise.
\end{abstract}

Keywords: business opportunity, entrepreneurial venture, franchise, franchisee 


\section{LITERATURA}

1. Barringer, B. R. i Ireland, R. D. (2016). Entrepreneurship - Successfully Launching New Ventures (5th ed.- Global Ed.). SAD: Pearson.

2. Bijeli svijet. (2017). Franšizni koncept praonice rublja LG Laundry Lounge. Preuzeto s https:// www.bijelisvijet.hr/novosti/20/fransizni-koncept-praonice-rublja-lg-laundry-lounge/ (12.06.2020.)

3. Boroian, D. D. i Boroian, P. J. (1987). The Franchise Advantage - Make it work for you., SAD: Chicago Review Pr.

4. Boroian, D. D. i Mancuso, J. (1993). How to Buy and Manage a Franchise. SAD: Fireside - The Center for Entrepereneurial Management.

5. Brusić, A., Cvitanović, V., Gregov, Z., Kutnjak, V., Tomić, D. i Žanić, V. (2009). Poduzetništvo 1. Zagreb: Grupa Vern.

6. Businesswire, (2019). Global dry cleaning laundry services market report. Preuzeto s https:// www.businesswire.com/news/home/20191120005826/en/Global-Dry-Cleaning-Laundry-Services-Market-Report-2019-2022 (20.05.2020.)

7. Castrogiovanni, G. J. i Justis, R. T. (1998). Franchising configurations and transitions. Journal of Consumer Marketing, 15(2), $170-190$.

8. Dugan, A. (1998). Franchising 101 - The Complete guide to Evaluationg, Buying and Growing Your Franchise Business. Chicago, SAD: Dearborn.

9. Dwivedy, R. (2002). Franchising Indeed Could Become the Business Ambassador of World Peace through Global Economic Prosperity. Franchising World, 34(3), 17.

10. Emerson, R. (1990). Franchising and The Collective Rights of Franchisees. Vanderbilt Law Review, 43, 1523-1532.

11. Erceg, A. (2017). Franšiza - Način pokretanja poduzetničkog pothvata i strategija rasta poslovanja. Osijek: Sveučilište Josipa Jurja Strossmayera u Osijeku, Ekonomski fakultet u Osijeku.

12. Hisrich, R. D., Peters M. P. i Shepherd, D. A. (2011). Poduzetništvo. Zagreb: MATE d.o.o.

13. Keup, E. J. (2000). Franchise Bible - How to buy a franchise or franchise your own business (4th edition). SAD: Oasis press.

14. Mlikotin-Tomić, D. (2000). Ugovor o franchisingu i pravo konkurenciji. Pravo u gospodarstvu, 39(4), $54-73$.

15. Mr. Jeff (2020). Why invest in a laundry franchise? Preuzeto s https://franchise.wearejeff.com/ news/are-laundry-franchises-good-business-opportunities (15.7.2020.)

16. Murray, I. (2003). How To Choose A Franchise. Velika Britanija: Express Newspapers.

17. Pressto. (2020). The secret of the success of Pressto Dry Cleaning and Laundry franchise. Preuzeto s https://www.pressto.com/pressto-franchise/ (10.7.2020.)

18. Seid, M. i Thomas, D. (2006). Franchising for Dummies (2nd edition). SAD: Wiley Publishing Inc.

19. Spasić, I. (1996). Franchising posao. Beograd: Institut za uporedno pravo.

20. Stanworth, J. (1991). Franchising and the Franchise Relationship, Director. International Journal of Retail Distribution and Consumer Research, 1(2), 175 - 191.

21. Timmons, J. A. (1999). New Venture Creation. Entrepreneurship for the 21st Century. SAD: Irwin/McGraw-Hill.

22. Tkalec Verčić, A., Sinčić Ćorić, D. i Pološki Vokić, N. (2010). Priručnik za metodologiju istraživačkog rada. Zagreb: M.E.P.

23. Tomzack, M. E. (2002). Tips \& Traps When Buying a Franchise. SAD: Source Book Publications.

24. Weber, R. A. (2013). An Introduction to Franchising. Velika Britanija: Palmgrave Macmillan. 